Article

\title{
Secondary Metabolites from the Roots of Beilschmiedia tsangii and Their Anti-Inflammatory Activities
}

\author{
Yun-Ting Huang ${ }^{1, \dagger}$, Hsun-Shuo Chang ${ }^{1, \dagger}$, Guei-Jane Wang ${ }^{2,3}$, Chu-Hung Lin ${ }^{4}$ and \\ Ih-Sheng Chen ${ }^{1,4, *}$
}

1 Graduate Institute of Natural Products, College of Pharmacy, Kaohsiung Medical University, Kaohsiung 80708, Taiwan; E-Mails: leave.alone@hotmail.com (Y.-T.H.); hschang@kmu.edu.tw (H.-S.C.)

2 L5 Research Center, China Medical University Hospital, Taichung 40447, Taiwan; E-Mail: jennyw355@gmail.com

3 Graduate Institute of Clinical Medical Science, China Medical University, Taichung 40402, Taiwan

4 School of Pharmacy, College of Pharmacy, Kaohsiung Medical University, Kaohsiung 80708, Taiwan; E-Mail: u96830006@kmu.edu.tw

$\dagger$ These authors contributed equally to this work.

* Author to whom correspondence should be addressed; E-Mail: m635013@kmu.edu.tw; Tel.: +886-7-312-1101 (ext. 2191); Fax: +886-7-321-0683.

Received: 24 September 2012; in revised form: 19 November 2012 / Accepted: 21 November 2012 / Published: 3 December 2012

\begin{abstract}
Four new endiandric acid analogues, tsangibeilin C (1), tsangibeilin D (2), tricyclotsangibeilin (3) and endiandric acid M (4), one new lignan, beilschminol B (5) and two new sesquiterpenes, (+)-5-hydroxybarbatenal (6) and $(4 R, 5 R)-4,5$-dihydroxycaryophyll8(13)-ene (7), together with four known compounds (8-11), were isolated from the roots of Beilschmiedia tsangii (Lauraceae). The structures of 1-7 were determined by spectroscopic techniques. Among the isolates, endiandric acid M (4) exhibited moderate iNOS inhibitory activity, with an $\mathrm{IC}_{50}$ value of $31.70 \mu \mathrm{M}$.
\end{abstract}

Keywords: Beilschmiedia tsangii; Lauraceae; root; endiandric acid; anti-inflammatory activity 


\section{Introduction}

Over 40 species of Formosan lauraceous plants have been screened for anti-inflammatory activity using an inducible nitric oxide synthase (iNOS) assay. A methanolic extract of the roots of B. tsangii Merr. (Lauraceae) has shown potent inhibition of NO production, with no cytotoxicity against RAW 264.7 cells. B. tsangii is a medium-sized evergreen tree, distributed throughout Tonkin, Vietnam, southern and western China and southern Taiwan. About 200 Beilschmiedia species are found in these tropical regions, including two species in Taiwan [1]. Our previous study reported two new tetrahydrofuran-type lignans, beilschmin A and beilschmin B, two new 1-phenylbutyl benzoates, tsangin $\mathrm{A}$ and tsangin $\mathrm{B}$, together with thirteen known compounds isolated from the stem of this plant [2]. One year later, three new epoxyfuranoid lignans, 4 $\alpha, 5 \alpha$-epoxybeilschmin A, $4 \alpha, 5 \alpha$-epoxybeilschmin B and beilschmin D, together with nine known compounds, were obtained from the leaves [3]. More recently, six new endiandric acid analogues, tsangibeilin A, tsangibeilin B, endiandramide $\mathrm{A}$, endiandric acid $\mathrm{K}$, endiandric acid $\mathrm{L}$ and endiandramide $\mathrm{B}$, two new lignans, beilschminol $\mathrm{A}$ and tsangin $\mathrm{C}$, and six known compounds have been obtained from the roots of this species [4]. In this continuation of our research, four new endiandric acid analogues, tsangibeilin C (1), tsangibeilin D (2), tricyclotsangibeilin (3) and endiandric acid M (4), one new lignan, beilschminol B (5) and two new sesquiterpenes: (+)-5-hydroxybarbatenal (6) and $(4 R, 5 R)-4,5$-dihydroxycaryophyll8(13)-ene (7), together with four known compounds (8-11), have been isolated from the roots of this plant. The structures of 1-7 were determined by spectroscopic techniques. This paper elucidates the structures of 1-7 (Figure 1). Endiandric acid M (4) exhibited moderate iNOS inhibitory activity, with an $\mathrm{IC}_{50}$ value of $31.70 \mu \mathrm{M}$.

Figure 1. Structures of compounds 1-11.

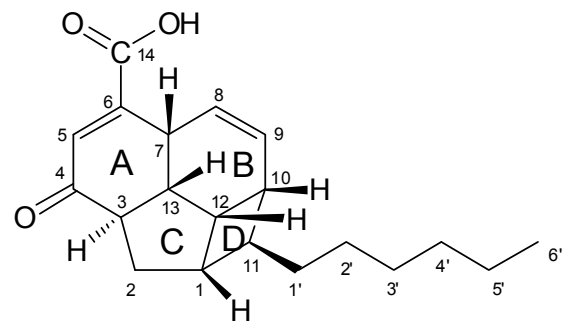

1

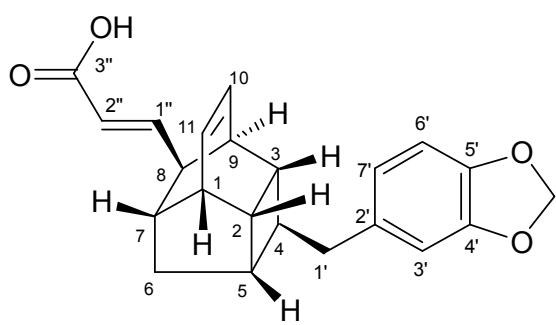

4

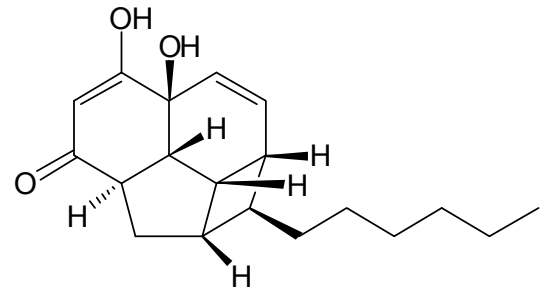

2<smiles>COc1cc(C2O[C](c3cc(OC)c(OC)c(OC)c3)[C@H](C)[C@H]2C)cc(O)c1OC</smiles>

5

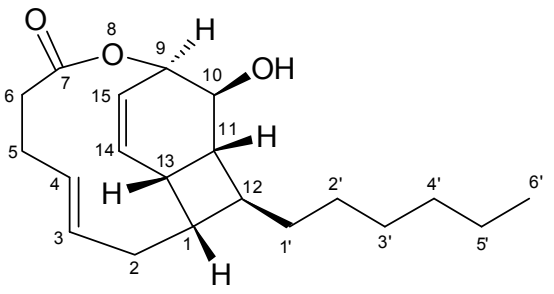

3

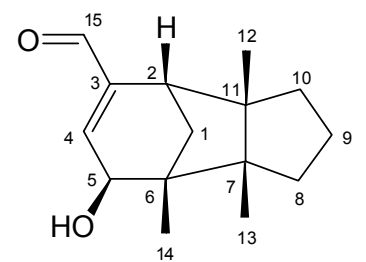

6 
Figure 1. Cont.



7

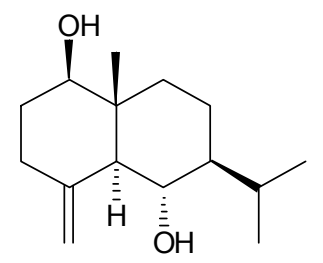

10<smiles>COc1cc(C=O)cc(OC)c1OC</smiles>

8

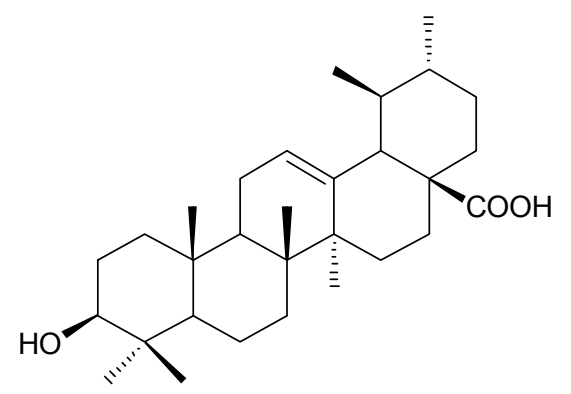

11

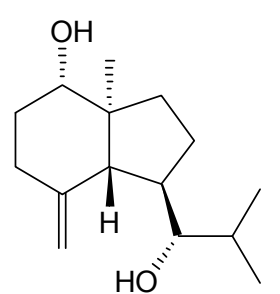

9

\section{Results and Discussion}

\subsection{Structure Elucidation}

Compound 1 was isolated as a light yellowish oil. Its molecular formula was established as $\mathrm{C}_{20} \mathrm{H}_{26} \mathrm{O}_{3}$ by ESIMS and HRESIMS, with eight unsaturated degrees. The IR spectrum showed absorptions at $1696 \mathrm{~cm}^{-1}$ for carbonyl groups ( $\delta 201.6, \mathrm{C}-4$ and $\left.\delta 168.3, \mathrm{C}-14\right)$ and at $3432 \mathrm{~cm}^{-1}$ for a hydroxy group of carboxylic acid. These findings were supported by ${ }^{13} \mathrm{C}$ NMR spectrum. The ${ }^{1} \mathrm{H},{ }^{13} \mathrm{C}$ NMR (Table 1), COSY (Figure 2), HSQC and HMBC (Figure 2) spectra of 1 were similar to those of beilschmiedic acid D [5] and also contained 13 skeletal signals of an endiandric acid moiety. The characteristic two cis olefinic protons at $\delta 5.56$ (ddd, $J=10.2,3.0,1.8 \mathrm{~Hz}, \mathrm{H}-8$ ) and 5.85 (ddd, $J=10.2,4.2,3.0 \mathrm{~Hz}, \mathrm{H}-9$ ) in $\mathbf{1}$ were similar to those of beilschmiedic acid $\mathrm{D}$, but the signal for another olefinic proton in 1 was shifted upfield to $\delta 6.70$ (d, $J=1.2 \mathrm{~Hz}, \mathrm{H}-5)$, because a carbonyl group $\left(\delta_{\mathrm{C}} 201.6, \mathrm{C}-4\right)$ in 1 replaced a methylene group $\left[\delta 2.06\left(\mathrm{~m}, \mathrm{H}_{\mathrm{a}}-4\right)\right.$ and $2.54(\mathrm{dt}, J=8.8,3.1 \mathrm{~Hz}$, $\left.\mathrm{H}_{\mathrm{b}}-4\right)$ ] in beilschmiedic acid $\mathrm{D}$. The length of the alkyl side chain at $\mathrm{C}-11$ of $\mathbf{1}$ was two methylenes less than beilschmiedic acid $\mathrm{D}$, as supported by the molecular formula of $\mathbf{1}\left(\mathrm{C}_{20} \mathrm{H}_{26} \mathrm{O}_{3}\right)$. The rigid tetracyclic skeleton was indicated by HMBC correlations, including: $\mathrm{H}-5$ to $\mathrm{C}-3, \mathrm{C}-6, \mathrm{C}-7$ and C-14, H-3 to C-4, and C-7, H-13 to C-8 and C-10, H-8 to C-6 and C-10, H-9 to C-7, H-2 to C-3, C-4, C-11 and $\mathrm{C}-13, \mathrm{H}-1$ to $\mathrm{C}-3$ and $\mathrm{C}-13, \mathrm{H}-12$ to $\mathrm{C}-3, \mathrm{C}-9$ and $\mathrm{C}-11$ and $\mathrm{H}-11$ to $\mathrm{C}-9$. The relative configuration of $\mathbf{1}$, rel-( $(1 S, 3 R, 7 R, 10 R, 11 S, 12 S, 13 S)$, was supported on the basis of NOESY (Figure 3) and structural similarity with beilschmiedic acid D [5]. There are seven chiral centers in $\mathbf{1}$. However, in view of the observed optical rotation $\left([\alpha]_{\mathrm{D}}^{23} \pm 0\right), \mathbf{1}$ should be racemic, as are many endiandric acid

analogues [6-9]. According to the above data, the structure of $\mathbf{1}$ was elucidated and named tsangibeilin $\mathrm{C}$. 
Table 1. ${ }^{1} \mathrm{H}(600 \mathrm{MHz})$ and ${ }^{13} \mathrm{C}(150 \mathrm{MHz}) \mathrm{NMR}$ data of $\mathbf{1}$ (acetone- $\left.d_{6}\right)$ and $2\left(\mathrm{CD}_{3} \mathrm{OD}\right)$.

\begin{tabular}{|c|c|c|c|c|}
\hline \multirow{2}{*}{ position } & \multicolumn{2}{|r|}{1} & \multicolumn{2}{|r|}{2} \\
\hline & $\delta_{\mathrm{C}}$ & $\delta_{\mathrm{H}}(J$ in $\mathrm{Hz})$ & $\delta_{\mathrm{C}}$ & $\delta_{\mathrm{H}}(J$ in $\mathbf{H z})$ \\
\hline 1 & $41.6(\mathrm{CH})$ & $2.36, \mathrm{~m}$ & $42.0(\mathrm{CH})$ & 2.41, br dd $(12.0,6.0)$ \\
\hline 2 & $31.5\left(\mathrm{CH}_{2}\right)$ & $\begin{array}{c}1.56, \operatorname{td}(12.0,6.0) \\
1.65, \text { br dd }(12.0,5.4)\end{array}$ & $31.0\left(\mathrm{CH}_{2}\right)$ & $\begin{array}{c}1.57, \operatorname{td}(12.0,6.0) \\
1.62, \text { br dd }(12.0,5.4)\end{array}$ \\
\hline 3 & $50.5(\mathrm{CH})$ & 3.05, ddd $(13.5,12.0,5.4)$ & $54.3(\mathrm{CH})$ & $2.94, \operatorname{ddd}(13.2,12.0,5.2)$ \\
\hline 4 & $201.6(\mathrm{C})$ & - & $203.7(\mathrm{C})$ & - \\
\hline 5 & $135.8(\mathrm{CH})$ & $6.70, \mathrm{~d}(1.2)$ & $132.3(\mathrm{CH})$ & $6.54, \mathrm{~s}$ \\
\hline 6 & $151.5(\mathrm{C})$ & - & $158.5(\mathrm{C})$ & - \\
\hline 7 & $36.2(\mathrm{CH})$ & 3.51 , br s & $71.2(\mathrm{C})$ & - \\
\hline 8 & $123.5(\mathrm{CH})$ & $5.56, \operatorname{ddd}(10.2,3.0,1.8)$ & $125.9(\mathrm{CH})$ & 6.01 , br d (10.2) \\
\hline 9 & $131.5(\mathrm{CH})$ & $5.85, \operatorname{ddd}(10.2,4.2,3.0)$ & $132.6(\mathrm{CH})$ & $5.87, \mathrm{dd}(10.2,4.2)$ \\
\hline 10 & $35.8(\mathrm{CH})$ & $2.40, \mathrm{~m}$ & $35.9(\mathrm{CH})$ & $2.47, \mathrm{~m}$ \\
\hline 11 & $48.0(\mathrm{CH})$ & $1.47, \mathrm{~m}$ & $47.9(\mathrm{CH})$ & $1.45, \mathrm{~m}$ \\
\hline 12 & $35.2(\mathrm{CH})$ & $2.87, \mathrm{~m}$ & $32.9(\mathrm{CH})$ & 2.97, br dd $(8.4,6.0)$ \\
\hline 13 & $44.8(\mathrm{CH})$ & $2.35, \mathrm{~m}$ & $51.9(\mathrm{CH})$ & 2.24, ddd $(13.2,8.4,1.2)$ \\
\hline 14 & $168.3(\mathrm{C})$ & - & - & - \\
\hline $1^{\prime}$ & $38.4\left(\mathrm{CH}_{2}\right)$ & $1.54, \mathrm{~m}$ & $38.2\left(\mathrm{CH}_{2}\right)$ & $1.54, \mathrm{~m}$ \\
\hline $2^{\prime}$ & $28.3\left(\mathrm{CH}_{2}\right)$ & $1.28, \mathrm{~m}$ & $28.0\left(\mathrm{CH}_{2}\right)$ & $1.25, \mathrm{~m}$ \\
\hline $3^{\prime}$ & $31.0\left(\mathrm{CH}_{2}\right)$ & $1.28, \mathrm{~m}$ & $30.4\left(\mathrm{CH}_{2}\right)$ & $1.28, \mathrm{~m}$ \\
\hline $4^{\prime}$ & $33.2\left(\mathrm{CH}_{2}\right)$ & $1.28, \mathrm{~m}$ & $33.0\left(\mathrm{CH}_{2}\right)$ & $1.28, \mathrm{~m}$ \\
\hline $5^{\prime}$ & $23.9\left(\mathrm{CH}_{2}\right)$ & $1.28, \mathrm{~m}$ & $23.7\left(\mathrm{CH}_{2}\right)$ & $1.30, \mathrm{~m}$ \\
\hline $6^{\prime}$ & $15.0\left(\mathrm{CH}_{3}\right)$ & $0.88, \mathrm{t}(7.2)$ & $14.4\left(\mathrm{CH}_{3}\right)$ & $0.90, \mathrm{t}(6.9)$ \\
\hline
\end{tabular}

Figure 2. $\operatorname{COSY}(-)$ and HMBC ( $)$ connectivities for compounds 1-7.

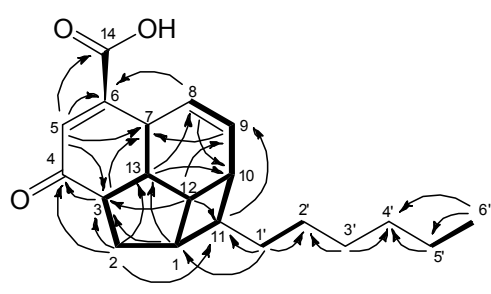

1

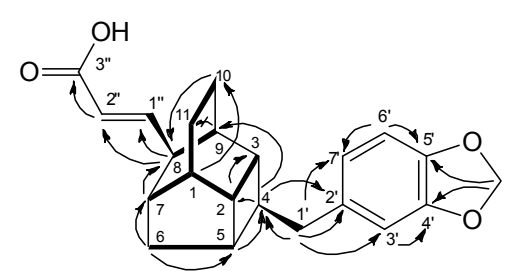

4

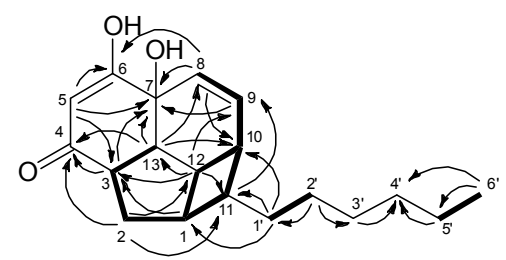

2



5

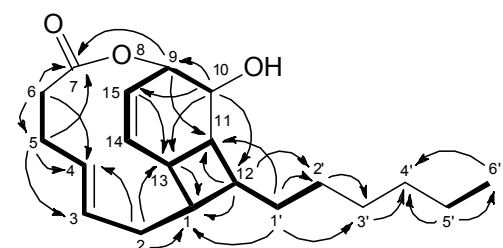

3

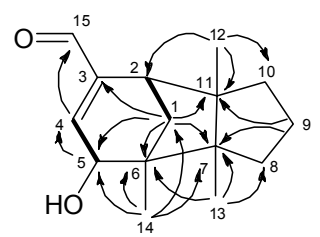

6 
Figure 2. Cont.

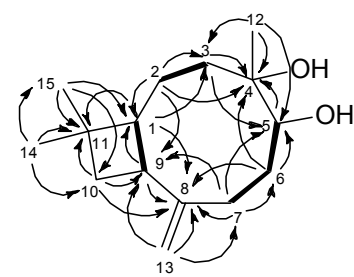

7

Analysis of the ESIMS and HREIMS of 2 revealed a molecular formula of $\mathrm{C}_{19} \mathrm{H}_{26} \mathrm{O}_{3}$, representing seven degrees of unsaturation, one carbon and one degree of unsaturation less than compound 1 $\left(\mathrm{C}_{20} \mathrm{H}_{26} \mathrm{O}_{3}\right)$. The IR spectrum indicated the presence of a hydroxy group $\left(3397 \mathrm{~cm}^{-1}\right)$ and a carbonyl group $\left(1692 \mathrm{~cm}^{-1}\right)$. The rigid tetracyclic skeleton of $\mathbf{2}$ was the same as that of $\mathbf{1}$, according to its ${ }^{1} \mathrm{H}$ and ${ }^{13} \mathrm{C}$ NMR spectra (Table 1), inclusive of COSY (Figure 2), NOESY (Figure 3), HSQC and HMBC (Figure 2) experiments. The major differences between $\mathbf{1}$ and $\mathbf{2}$ were two hydroxy groups at C-6 and C-7 in 2 were substituted for the carboxyl group $(\delta 168.3, \mathrm{C}-14)$ and $\mathrm{H}-7$ [ $\delta_{\mathrm{H}} 3.51(1 \mathrm{H}$, br s)] at C-6 and C-7 in 1, as supported by HRESIMS, IR and DEPT spectra. The NOESY spectrum (Figure 3) showed correlations between $\mathrm{H}_{\mathrm{a}}-2, \mathrm{H}-3$ and $\mathrm{H}-11$, but these three protons showed no correlations with $\mathrm{H}-1, \mathrm{H}_{\mathrm{b}}-2, \mathrm{H}-10, \mathrm{H}-12$ and $\mathrm{H}-13$. This suggested that $\mathrm{H}_{\mathrm{a}}-2, \mathrm{H}-3$ and $\mathrm{H}-11$ are on the same side of the molecule, and that $\mathrm{H}-1, \mathrm{H}_{\mathrm{b}}-2, \mathrm{H}-10, \mathrm{H}-12$ and $\mathrm{H}-13$ are on the opposite side of the molecule. The $\beta$-orientation of the hydroxy group at $\mathrm{C}-7$ was attributed according to the structural similarity with endiandric acid analogues and biogenetic consideration, where the rings $\mathrm{A} / \mathrm{B}, \mathrm{B} / \mathrm{C}, \mathrm{C} / \mathrm{D}$ and $\mathrm{B} / \mathrm{D}$ were cis-fusion and ring $\mathrm{A} / \mathrm{C}$ was trans-fusion [4,8,9]. The relative configuration of 2, rel-( $(1 S, 3 R, 7 R, 10 R, 11 S, 12 S, 13 S)$ was supported on the basis of NOESY and structural similarity with beilschmiedic acid D [5]. On the basis of the observations above, compound 2 was elucidated and named tsangibeilin D.

Figure 3. NOESY ( ) connectivities for compounds 1-7.



1

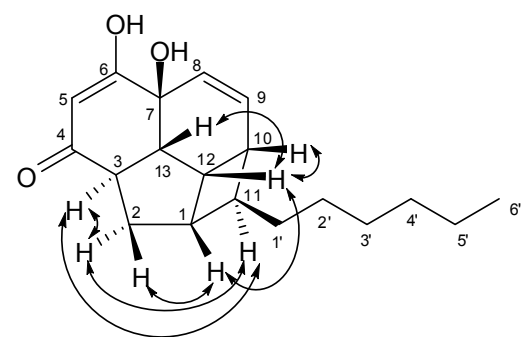

2

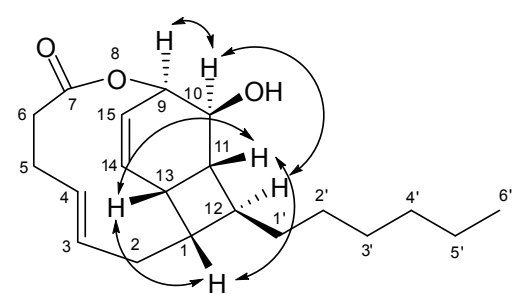

3 
Figure 3. Cont.
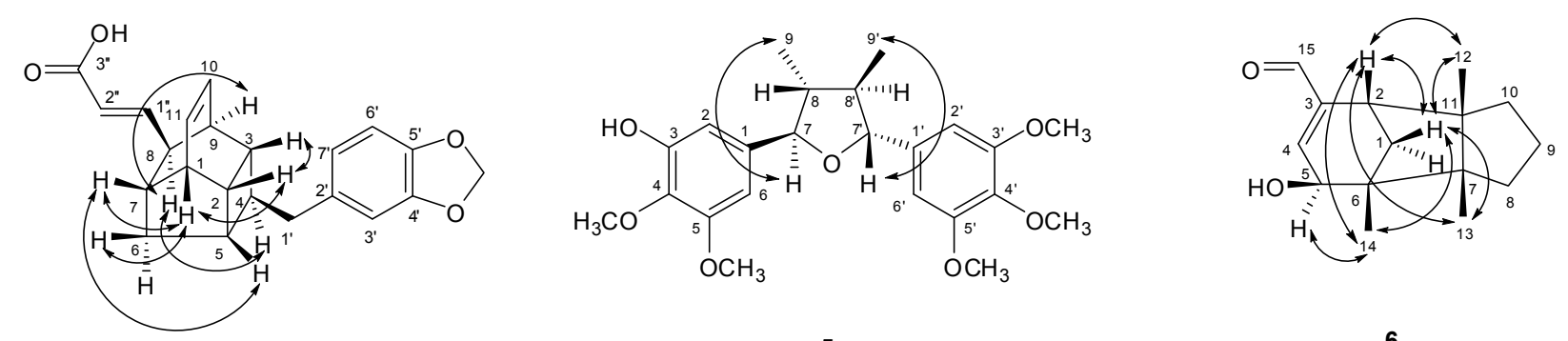

4

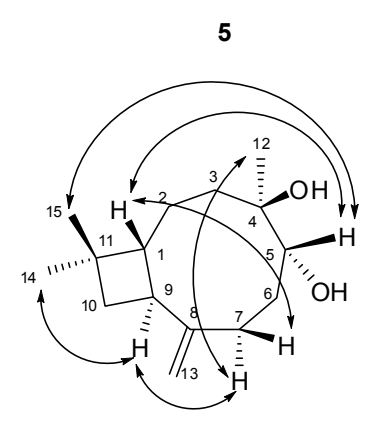

7

Compound 3 was obtained as an optically active light yellowish oil with $[\alpha]_{\mathrm{D}}^{24}+36.3(c 0.024$, $\mathrm{CHCl}_{3}$ ). IR absorption bands at $3422 \mathrm{~cm}^{-1}(\mathrm{OH})$ and $1729 \mathrm{~cm}^{-1}$ (ester carbonyl) were observed. The ESIMS analysis of 3 showed the $[\mathrm{M}+\mathrm{Na}]^{+}$ion at $\mathrm{m} / z$ 341, in agreement with the molecular formula of $\mathrm{C}_{20} \mathrm{H}_{30} \mathrm{O}_{3}$, with six degrees of unsaturation as confirmed by HRESIMS. The ${ }^{13} \mathrm{C}$ NMR (Table 2) and DEPT spectra indicated that 3 contains one methyl, eight methylenes, ten methines and one quaternary carbon. The HSQC and COSY (Figure 2) spectra revealed three fragments, C1-C2-C3-C4-C5-C6, $\mathrm{C} 1-\mathrm{C} 13-\mathrm{C} 11-\mathrm{C} 12-\mathrm{C} 1$ and $\mathrm{C}-13-\mathrm{C} 14-\mathrm{C} 15-\mathrm{C} 9-\mathrm{C} 10$, and the HMBC (Figure 2) correlations, H-10 to $\mathrm{C}-9, \mathrm{C}-12, \mathrm{C}-13$ and $\mathrm{C}-15$ and $\mathrm{H}-9$ to $\mathrm{C}-11$, connected the fragments $\mathrm{C} 1-\mathrm{C} 13-\mathrm{C} 11-\mathrm{C} 12-\mathrm{C} 1$ and $\mathrm{C}-13-\mathrm{C} 14-\mathrm{C} 15-\mathrm{C} 9-\mathrm{C} 10$ to form a cyclohexane ring fused with a cyclobutane ring. The carboxyl group ( $\delta$ 173.5, C-7) connected the fragment $\mathrm{C} 1-\mathrm{C} 2-\mathrm{C} 3-\mathrm{C} 4-\mathrm{C} 5-\mathrm{C} 6$ with the cyclohexane ring, as supported by HMBC correlations, H-6 to C-4, C-5 and C-7, H-5 to C-3 and C-7 and H-9 to C-7. According to the above evidence, the carboxyl group, the fragment $\mathrm{C} 1-\mathrm{C} 2-\mathrm{C} 3-\mathrm{C} 4-\mathrm{C} 5-\mathrm{C} 6$, the cyclohexane ring and the cyclobutane ring become a cyclododecane ring, which is also supported by six degrees of unsaturation. The HMBC spectrum showed correlations between $\mathrm{H}-1^{\prime}$ and $\mathrm{C}-1, \mathrm{C}-11, \mathrm{C}-2$ ' and C-3', thus establishing the presence of an alkyl chain (C-1' C-6') to be connected at C-12. Finally, the HRESIMS, IR, and DEPT spectra indicated the presence of a hydroxy group located at C-10. The NOESY spectrum (Figure 3) showed correlations between H-9, H-10 and H-12, suggesting these three protons were on the same side of the molecule, but $\mathrm{H}-1, \mathrm{H}-11$ and $\mathrm{H}-13$ showed no correlations with $\mathrm{H}-9, \mathrm{H}-10$ and H-12, which should therefore be on the opposite side of the molecule. The relative configuration of $\mathbf{3}$, rel-( $1 S, 9 R, 10 S, 11 R, 12 S, 13 S)$, was supported on the basis of NOESY and its structural similarity with know endiandric acid analogues. Based on further spectrographic evidence, the structure of $\mathbf{3}$ was elucidated and designated as tricyclotsangibeilin. 
Table 2. ${ }^{1} \mathrm{H}(600 \mathrm{MHz})$ and ${ }^{13} \mathrm{C}(150 \mathrm{MHz}) \mathrm{NMR}$ data of $\mathbf{3}\left(\mathrm{CDCl}_{3}\right)$ and 4 (acetone- $\left.d_{6}\right)$.

\begin{tabular}{|c|c|c|c|c|}
\hline \multirow{2}{*}{ position } & \multicolumn{2}{|r|}{3} & \multicolumn{2}{|r|}{4} \\
\hline & $\delta_{\mathrm{C}}$ & $\delta_{\mathrm{H}}(J$ in $\mathrm{Hz})$ & $\delta_{\mathrm{C}}$ & $\delta_{\mathrm{H}}(J$ in $\mathrm{Hz})$ \\
\hline 1 & $41.9(\mathrm{CH})$ & $2.37, \mathrm{~m}$ & $43.7(\mathrm{CH})$ & 2.72, br dd $(12.0,5.4)$ \\
\hline \multirow[t]{2}{*}{2} & $31.8\left(\mathrm{CH}_{2}\right)$ & $1.28, \mathrm{~m}$ & $41.3(\mathrm{CH})$ & $2.45, \mathrm{dt}(9.0,5.4)$ \\
\hline & & 1.99, ddd $(14.4,9.6,4.8)$ & & \\
\hline 3 & $132.3(\mathrm{CH})$ & $5.50, \operatorname{ddd}(15.6,9.6,6.0)$ & $41.1(\mathrm{CH})$ & $1.72, \mathrm{~m}$ \\
\hline 4 & $130.1(\mathrm{CH})$ & 5.24, ddd $(15.6,9.6,5.4)$ & $41.2(\mathrm{CH})$ & 2.25, brt $(7.8)$ \\
\hline 5 & $31.2\left(\mathrm{CH}_{2}\right)$ & $2.38, \mathrm{~m}$ & $41.0(\mathrm{CH})$ & $2.36, \mathrm{~m}$ \\
\hline \multirow[t]{2}{*}{6} & $34.3\left(\mathrm{CH}_{2}\right)$ & 2.29, ddd $(11.4,5.4,2.4)$ & $39.9\left(\mathrm{CH}_{2}\right)$ & 1.63, br d (12.3) \\
\hline & & $2.22, \mathrm{~m}$ & & 1.87, br dd $(12.3,5.4)$ \\
\hline 7 & $173.5(\mathrm{C})$ & - & $43.4(\mathrm{CH})$ & 1.89, br dd $(9.0,5.4)$ \\
\hline 8 & - & - & $48.2(\mathrm{CH})$ & 2.91, br dd $(8.2,3.6)$ \\
\hline 9 & $70.1(\mathrm{CH})$ & $4.87, \mathrm{dt}(5.6,2.4)$ & $38.8(\mathrm{CH})$ & $2.53, \mathrm{~m}$ \\
\hline 10 & $67.2(\mathrm{CH})$ & 3.96, br d (7.2) & $134.2(\mathrm{CH})$ & 6.19, brt $(7.2)$ \\
\hline 11 & $40.8(\mathrm{CH})$ & $2.21, \mathrm{~m}$ & $131.9(\mathrm{CH})$ & 6.25, brt $(7.2)$ \\
\hline 12 & $33.3(\mathrm{CH})$ & 3.18, br dt $(15.6,7.5)$ & - & - \\
\hline 13 & $30.9(\mathrm{CH})$ & $3.02, \mathrm{~m}$ & - & - \\
\hline 14 & $136.0(\mathrm{CH})$ & $6.16, \mathrm{dd}(10.4,6.0)$ & - & - \\
\hline 15 & $123.9(\mathrm{CH})$ & $6.25, \mathrm{dd}(10.4,5.6)$ & - & - \\
\hline \multirow[t]{2}{*}{$1^{\prime}$} & $36.3\left(\mathrm{CH}_{2}\right)$ & $1.47, \mathrm{q}(7.5)$ & $43.1\left(\mathrm{CH}_{2}\right)$ & $2.78, \mathrm{dd}(15.6,7.8)$ \\
\hline & & & & 2.81, br d $(7.8)$ \\
\hline $2^{\prime}$ & $27.7\left(\mathrm{CH}_{2}\right)$ & $1.27-1.33, \mathrm{~m}$ & $136.5(\mathrm{C})$ & - \\
\hline $3^{\prime}$ & $29.5\left(\mathrm{CH}_{2}\right)$ & $1.27-1.33, \mathrm{~m}$ & $110.5(\mathrm{CH})$ & $6.75, \mathrm{~d}(1.8)$ \\
\hline $4^{\prime}$ & $31.9\left(\mathrm{CH}_{2}\right)$ & $2.24, \mathrm{~m}$ & $149.2(\mathrm{C})$ & - \\
\hline $5^{\prime}$ & $22.7\left(\mathrm{CH}_{2}\right)$ & $1.27-1.33, \mathrm{~m}$ & $147.3(\mathrm{C})$ & - \\
\hline $6^{\prime}$ & $14.1\left(\mathrm{CH}_{3}\right)$ & $0.90, \mathrm{t}(6.9)$ & $109.3(\mathrm{CH})$ & $6.74, \mathrm{~d}(7.8)$ \\
\hline $7^{\prime}$ & - & - & $123.1(\mathrm{CH})$ & $6.68, \mathrm{dd}(7.8,1.8)$ \\
\hline $1 "$ & - & - & $155.3(\mathrm{CH})$ & $6.72, \mathrm{dd}(15.6,8.2)$ \\
\hline $2^{\prime \prime}$ & - & - & $121.3(\mathrm{CH})$ & $5.71, \mathrm{dd}(15.6,0.9)$ \\
\hline $3^{\prime \prime}$ & - & - & $168.4(\mathrm{C})$ & - \\
\hline $\mathrm{OCH}_{2} \mathrm{O}$ & - & - & $102.3\left(\mathrm{CH}_{2}\right)$ & $5.94, \mathrm{~s}$ \\
\hline
\end{tabular}

ESIMS and HRESIMS data of compound 4 indicated the molecular formula $\mathrm{C}_{22} \mathrm{H}_{22} \mathrm{O}_{4}$, four methylenes less than endiandric acid L [4] with 12 degrees of unsaturation, which was the same as endiandric acid L. The UV, IR, ${ }^{1} \mathrm{H}$ NMR (Table 2) and ${ }^{13} \mathrm{C}$ NMR (Table 2) spectra were similar to those of endiandric acid $\mathrm{L}$, except that a methylene group $\left[\delta 2.78\left(1 \mathrm{H}, \mathrm{dd}, J=15.6,7.8 \mathrm{~Hz}, \mathrm{H}_{\mathrm{a}}-1^{\prime}\right)\right.$, $2.81\left(1 \mathrm{H}\right.$, br d, $\left.\left.J=7.8 \mathrm{~Hz}, \mathrm{H}_{\mathrm{b}}-1^{\prime}\right)\right]$ in 4 replaced the pentamethylene group in endiandric acid $\mathrm{L}$. The relative configuration of $\mathbf{4}$ was supported by NOESY spectrum and its structural similarity with endiandric acid L [4]. Thus, compound 4 was named endiandric acid M. Compounds 1, 2 and 4 were racemic, and all structures were determined by ${ }^{13} \mathrm{C}$ NMR, NOESY, COSY, HSQC and HMBC experiments (see Figures 2 and 3).

Compound 5 was obtained as an optically active light yellowish oil, $[\alpha]_{\mathrm{D}}^{25}-18.6(c 0.18, \mathrm{MeOH})$, and its molecular formula was established as $\mathrm{C}_{23} \mathrm{H}_{30} \mathrm{O}_{7}$ by ESIMS and HRESIMS. UV absorptions at 209, $240 \mathrm{sh}$, and $270 \mathrm{~nm}$, in conjunction with a bathochromic shift after the addition of alkali, 
indicated a phenolic benzenoid moiety. An IR absorption band at $3415 \mathrm{~cm}^{-1}(\mathrm{OH})$ was also observed. The ${ }^{1} \mathrm{H}$ NMR signals for a 7,7'-epoxylignan moiety $[\delta 1.07(3 \mathrm{H}, \mathrm{d}, J=6.0 \mathrm{~Hz}, \mathrm{H}-9$ ') $1.08(3 \mathrm{H}, \mathrm{d}$, $J=6.0 \mathrm{~Hz}, \mathrm{H}-9), 1.78(1 \mathrm{H}, \mathrm{m}, \mathrm{H}-8), 1.78\left(1 \mathrm{H}, \mathrm{m}, \mathrm{H}-8{ }^{\prime}\right), 4.61(1 \mathrm{H}, \mathrm{d}, J=8.8 \mathrm{~Hz}, \mathrm{H}-7)$ and $4.63(1 \mathrm{H}, \mathrm{d}$, $\left.\left.J=9.2 \mathrm{~Hz}, \mathrm{H}^{-} 7^{\prime}\right)\right]$ were similar to those of beilschminol A [4], except that $\mathrm{OCH}_{3}-3^{\prime}[\delta 3.88(3 \mathrm{H}, \mathrm{s})]$ and $\mathrm{OCH}_{3}-4^{\prime}[\delta 3.83(3 \mathrm{H}, \mathrm{s})]$ in 5 replaced a methylenedioxy group [ $\delta 5.96(2 \mathrm{H}$, each $\left.\mathrm{d}, J=1.4 \mathrm{~Hz})\right]$ in beilschminol A. Thus, the planar structure of $\mathbf{5}$ was proposed to be 3-hydroxy-4,5,3',4',5'pentamethoxy-7,7'-epoxylignan. The relative configuration of $\mathbf{5}$ was based on the NOESY spectrum and its structural similarity with $\left(7 R, 8 R, 7^{\prime} R, 8^{\prime} R\right)$-3-hydroxy-3', $4^{\prime}$-methylenedioxy-4,5,5'-trimethoxy-

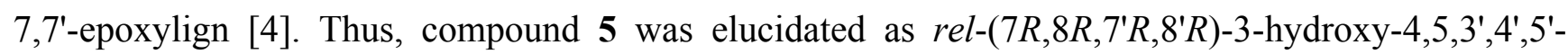
pentamethoxy-7,7'-epoxylignan and named beilschminol B.

Compound 6 was isolated as an optically active light yellowish oil, $[\alpha]_{\mathrm{D}}^{25}+123.8$ (c 0.06, $\left.\mathrm{CHCl}_{3}\right)$. The HRESIMS analysis of 6 gave a quasi-molecular ion peak at $m / z 257.1516[\mathrm{M}+\mathrm{Na}]^{+}$(calcd. for $\mathrm{C}_{15} \mathrm{H}_{22} \mathrm{O}_{2} \mathrm{Na}$, 257.1517), consistent with a molecular formula of $\mathrm{C}_{15} \mathrm{H}_{22} \mathrm{O}_{2}$ with five degrees of unsaturation. The IR, ${ }^{1} \mathrm{H}$, and ${ }^{13} \mathrm{C}$ NMR (Table 3) spectra resembled those of (+)-barbatenal [10], except that a hydroxy group and an oxymethine proton $[\delta 4.09(1 \mathrm{H}, \mathrm{d}, J=3.6, \mathrm{H}-5)]$ in $\mathrm{C}-5\left(\delta_{\mathrm{c}} 71.2\right)$ of 6 replaced a methylene $\left[\delta 1.65\left(1 \mathrm{H}, \mathrm{dd}, J=21.1,3.3 \mathrm{~Hz}, \mathrm{H}_{\mathrm{a}}-5\right), 2.04\left(1 \mathrm{H}, \mathrm{dd}, J=20.1,2.8 \mathrm{~Hz}, \mathrm{H}_{\mathrm{b}}-5\right)\right]$ in C-5 $\left(\delta_{\mathrm{c}} 41.9\right)$ of (+)-barbatenal, resulting in the downshifting of the olefinic proton $\left(\delta_{\mathrm{H}} 6.60, \mathrm{H}-4\right)$ in 6 from $\delta_{\mathrm{H}} 5.87(\mathrm{H}-4)$ in (+)-barbatenal. The relative configuration of $\mathbf{6}$ was determined by NOESY spectrum, where $\mathrm{H}_{\mathrm{a}}-1$ showed correlations with $\mathrm{H}-2, \mathrm{H}-12, \mathrm{H}-13$ and $\mathrm{H}-14$, but no correlation with $\mathrm{H}-5$. It has been suggested that $\mathrm{H}_{\mathrm{a}}-1, \mathrm{H}-2, \mathrm{H}-12, \mathrm{H}-13$ and $\mathrm{H}-14$ are on the same side of the molecule and that $\mathrm{H}_{\mathrm{b}}-1$ and $\mathrm{H}-5$ are on the opposite side of the molecule. Furthermore, H-5 showed a correlation with H-14 due to a spatial distance between these two protons of $<4 \AA$, as supported by simulating the ChemDraw 3D Ultra (version 10.0). Based on the NOESY spectrum, the optical rotation and comparison to values in the literature, the relative configuration of 6 was determined to be rel- $(2 \beta, 5 \alpha$, $12 \beta, 13 \beta, 14 \beta)$. Hence, the structure of 6 was elucidated and designated as $(+)-5$-hydroxybarbatenal, which was further confirmed by DEPT, HSQC, NOESY (Figure 3) and HMBC (Figure 2) techniques.

Compound 7 was isolated as an optically active light yellowish oil with $[\alpha]_{\mathrm{D}}^{25}-23.9$ (c 0.032 , $\left.\mathrm{CHCl}_{3}\right)$. IR absorption bands at $3396 \mathrm{~cm}^{-1}(\mathrm{OH})$ and $1637 \mathrm{~cm}^{-1}(\mathrm{C}=\mathrm{C})$ were observed. From the HRESIMS data, the molecular formula was determined to be $\mathrm{C}_{15} \mathrm{H}_{26} \mathrm{O}_{2}\left(\mathrm{~m} / z 261.1828[\mathrm{M}+\mathrm{Na}]^{+}\right.$; calcd. 261.1830). The ${ }^{13} \mathrm{C}$ NMR (Table 3) and DEPT spectra indicated that 7 contains three methyls, six methylenes, three methines and three quaternary carbons, suggesting a sesquiterpene skeleton. The HSQC and COSY (Figure 2) spectra revealed the correlations from C1-C9, C2-C3 and C-5-C6-C7 and the HMBC (Figure 2) correlations, H-1 to C-3, C-8 and C-11, H-10 to C-8, C-9 and C-11, H-9 to C-1 and C-8, H-7 to C-5, C-6, C-8 and C-9, H-6 to C-4, C-5 and C-8, H-3 to C-4 and C-5 and H-2 to C-1, $\mathrm{C}-3, \mathrm{C}-4$ and $\mathrm{C}-9$, connected the fragments $\mathrm{C} 1-\mathrm{C} 9, \mathrm{C} 2-\mathrm{C} 3$ and $\mathrm{C}-5-\mathrm{C} 6-\mathrm{C} 7$ to form a cyclononane ring and a cyclobutane ring. HMBC correlations, $\mathrm{H}-15$ to $\mathrm{C}-1, \mathrm{C}-10$ and $\mathrm{C}-11, \mathrm{H}-14$ to $\mathrm{C}-10, \mathrm{C}-11$ and C-15, H-12 to C-3, C-4 and C-5, H-13 to C-7, C-8 and C-9, confirmed that three methyl groups were connected at $\mathrm{C}-4$ and $\mathrm{C}-11$ and that a terminal double bond was present at C-8. Finally, the HRESIMS, IR, DEPT spectra indicated two hydroxy groups located at C-4 and C-5, respectively. The NOESY spectrum (Figure 3) showed correlations between $\mathrm{H}_{\mathrm{b}}-7, \mathrm{H}-9, \mathrm{H}-12$ and $\mathrm{H}-14$, suggesting these three protons were on the same side of the molecule, but $\mathrm{H}-1, \mathrm{H}-5, \mathrm{H}_{\mathrm{a}}-7$ and $\mathrm{H}-15$ showed no correlations with $\mathrm{H}_{\mathrm{b}}-7, \mathrm{H}-9, \mathrm{H}-12$ and $\mathrm{H}-14$ and, therefore, should be on the opposite side of the molecule. The 
structure of 7 was elucidated as $(4 R, 5 R)$-4,5-dihydroxycaryophyll-8(13)-ene and identified with its synthetic compound [11]. Though compound 7 has previously been reported as a reduction intermediate [11], our study is the first time to have isolated this compound from a natural source.

Table 3. ${ }^{1} \mathrm{H}(600 \mathrm{MHz})$ and ${ }^{13} \mathrm{C}(150 \mathrm{MHz}) \mathrm{NMR}$ data of $6\left(\mathrm{CDCl}_{3}\right)$ and $7\left(\mathrm{CDCl}_{3}\right)$.

\begin{tabular}{|c|c|c|c|c|}
\hline \multirow{2}{*}{ position } & \multicolumn{2}{|r|}{6} & \multicolumn{2}{|r|}{7} \\
\hline & $\delta_{\mathrm{C}}$ & $\delta_{\mathrm{H}}(J$ in $\mathrm{Hz})$ & $\delta_{\mathrm{C}}$ & $\delta_{\mathrm{H}}(J$ in $\mathrm{Hz})$ \\
\hline \multirow[t]{2}{*}{1} & $36.9\left(\mathrm{CH}_{2}\right)$ & 1.37, br d (12.0) & $56.9(\mathrm{CH})$ & $1.65, \operatorname{ddd}(10.2,3.6,1.8)$ \\
\hline & & 1.69, dd $(12.0,4.2)$ & & \\
\hline \multirow[t]{2}{*}{2} & $42.8(\mathrm{CH})$ & $2.64, \mathrm{~d}(4.2)$ & $23.2\left(\mathrm{CH}_{2}\right)$ & $1.33, \mathrm{~m}$ \\
\hline & & & & $1.66, \mathrm{~m}$ \\
\hline \multirow[t]{2}{*}{3} & $147.7(\mathrm{C})$ & - & $40.8\left(\mathrm{CH}_{2}\right)$ & $1.56, \operatorname{ddd}(15.0,8.4,1.8)$ \\
\hline & & & & 1.93, ddd $(15.0,11.1,2.1)$ \\
\hline 4 & $147.5(\mathrm{CH})$ & $6.60, \mathrm{dd}(3.6,0.6)$ & $75.1(\mathrm{C})$ & - \\
\hline 5 & $71.2(\mathrm{CH})$ & $4.09, \mathrm{~d}(3.6)$ & $73.3(\mathrm{CH})$ & 3.60 , br dd $(6.0,2.4)$ \\
\hline \multirow[t]{2}{*}{6} & $48.7(\mathrm{C})$ & - & $32.6\left(\mathrm{CH}_{2}\right)$ & $1.57, \mathrm{~m}$ \\
\hline & & & & $1.75, \mathrm{~m}$ \\
\hline \multirow[t]{2}{*}{7} & $56.9(\mathrm{C})$ & - & $34.7\left(\mathrm{CH}_{2}\right)$ & $2.05, \mathrm{~m}$ \\
\hline & & & & 2.43, ddd $(13.2,9.0,4.2)$ \\
\hline \multirow[t]{2}{*}{8} & $36.2\left(\mathrm{CH}_{2}\right)$ & $1.10, \mathrm{~m}$ & $151.8(\mathrm{C})$ & - \\
\hline & & $1.58, \mathrm{~m}$ & & \\
\hline 9 & $38.6\left(\mathrm{CH}_{2}\right)$ & $1.25, \mathrm{~m}$ & $42.3(\mathrm{CH})$ & $2.37, \mathrm{q}(10.2)$ \\
\hline \multirow[t]{2}{*}{10} & $27.1\left(\mathrm{CH}_{2}\right)$ & 1.32, br dd $(6.9,0.9)$ & $36.0\left(\mathrm{CH}_{2}\right)$ & $1.58, \mathrm{~m}$ \\
\hline & & $1.54, \mathrm{~m}$ & & $1.74, \mathrm{t}(10.2)$ \\
\hline 11 & $54.9(\mathrm{C})$ & - & $34.1(\mathrm{C})$ & - \\
\hline 12 & $26.9\left(\mathrm{CH}_{3}\right)$ & $1.089, \mathrm{~s}$ & $21.5\left(\mathrm{CH}_{3}\right)$ & $1.14, \mathrm{~s}$ \\
\hline \multirow[t]{2}{*}{13} & $24.2\left(\mathrm{CH}_{3}\right)$ & $0.96, \mathrm{~s}$ & $110.5\left(\mathrm{CH}_{2}\right)$ & $4.92, \mathrm{~d}(1.2)$ \\
\hline & & & & 4.94, d (1.2) \\
\hline 14 & $18.7\left(\mathrm{CH}_{3}\right)$ & $1.087, \mathrm{~s}$ & $22.1\left(\mathrm{CH}_{3}\right)$ & $0.98, \mathrm{~s}$ \\
\hline 15 & $193.3(\mathrm{CH})$ & $9.54, \mathrm{~s}$ & $30.1\left(\mathrm{CH}_{3}\right)$ & $1.00, \mathrm{~s}$ \\
\hline $\mathrm{OH}$ & - & - & - & 2.07, br s \\
\hline $\mathrm{OH}$ & - & - & - & 2.29, br d (3.0) \\
\hline
\end{tabular}

The known compounds, 3,4,5-trimethoxybenzaldehyde (8) [12], octahydro-4-hydroxy-3 $\alpha$-methyl-7methylene- $\alpha$-(1-methylethyl)-1 $H$-indene-1-methanol (9) [13,14], eudesm-4(15)-ene-1 $\beta, 6 \alpha$-diol (10) $[15,16]$ and ursolic acid (11) [17] were identified by comparison of their physical and spectroscopic data with values reported in the literature.

\subsection{Anti-inflammatory Activities}

$\mathrm{E}_{\max }(\%)$ and $\mathrm{IC}_{50}(\mu \mathrm{M})$ values of iNOS inhibitory activity of five compounds, including compounds 4, 5 and 11, and the two compounds, 6 $\beta$-hydroxystigmast-4-en-3-one and

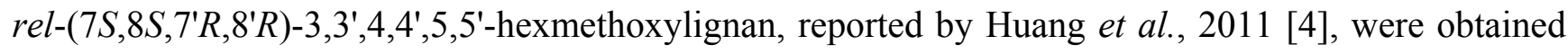
at the concentration range of 0.1 to $100 \mu \mathrm{M}$. Results are shown in Table 4 . The technique for the 
anti-iNOS activity assay was the same as in our previous study [4]. Among the isolates, endiandric acid M (4) exhibited moderate iNOS inhibitory activity, with $\mathrm{IC}_{50}$ value of $31.70 \mu \mathrm{M}$. Endiandramide $\mathrm{B}$ [4], endiandric acids K [4], L [4] and M, with the same skeleton but with different substituents at C-8, exhibited ascending degrees of iNOS inhibitory activity in this order: endiandramide B (16.40 $\mu \mathrm{M})>$ endiandric acid $\mathrm{M}(4)(31.70 \mu \mathrm{M})>$ endiandric acid $\mathrm{L}(39.56 \mu \mathrm{M})>$ endiandric acid $\mathrm{K}(58.21$ $\mu \mathrm{M})$. This suggests that the potency of the substituent at C-8 was an $N$-isobutylamido group $>$ an $\alpha, \beta$-unsaturated carboxylic acid group $>$ a carboxylic acid group. Endiandric acid M (4), with four fewer methylenes than endiandric acid L, showed stronger potency than endiandric acid L. This suggests that fewer methylenes in the alkyl side of endiandric acid analogues result in greater potency of iNOS inhibitory activity.

Table 4. Mean $\mathrm{E}_{\max }$ and $\mathrm{IC}_{50}$ of isolates from roots of $B$. tsangii on nitrite production induced by LPS in RAW 264.7 cells.

\begin{tabular}{|c|c|c|}
\hline Compounds & $E_{\max }(\%)^{a}$ & $\mathrm{IC}_{50}(\mu \mathrm{M})^{\mathrm{b}}$ \\
\hline endiandric acid M (4) & $97.03 \pm 1.30$ & $31.70 \pm 0.25$ \\
\hline beilschminol B (5) & $55.62 \pm 1.96$ & $95.37 \pm 0.52$ \\
\hline ursolic acid (11) & $36.55 \pm 4.66$ & $>100$ \\
\hline $6 \beta$-hydroxystigmast-4-en-3-one ${ }^{c}$ & $11.69 \pm 2.91$ & $>100$ \\
\hline rel-(7S,8S,7'R, $\left.8^{\prime} R\right)-3,4,5,3^{\prime}, 4^{\prime}, 5^{\prime}$-hexmethoxylignan ${ }^{c}$ & $52.67 \pm 5.05$ & $98.26 \pm 0.13$ \\
\hline aminoguanidine $^{\mathrm{d}}$ (a selective iNOS inhibitor) & $80.35 \pm 0.26$ & $26.55 \pm 0.48$ \\
\hline$N^{\omega}{ }^{-}$-nitro- ${ }_{\mathrm{L}}$-arginine ${ }^{\mathrm{d}}$ (a nonselective iNOS inhibitor) & $43.72 \pm 0.76$ & $152.46 \pm 10.53$ \\
\hline
\end{tabular}

${ }^{\mathrm{a}} \mathrm{E}_{\max }$ indicates mean maximum inhibitory effect, at a concentration of $100 \mu \mathrm{M}$, expressed as a percentage inhibition of nitrite production induced by LPS $(200 \mathrm{ng} / \mathrm{mL})$ in the presence of vehicle; ${ }^{b} \mathrm{IC}_{50}$ means the concentration producing $50 \% \mathrm{E}_{\max }$. $\left(n=4-6\right.$ in each group); ${ }^{\mathrm{c}}$ This compound was reported in Huang et al., $2011[4] ;{ }^{d}$ positive control.

\section{Experimental Section}

\subsection{General Experimental Procedures}

All melting points were measured on a Yanaco micro-melting apparatus and were uncorrected. Optical rotations were measured on a Jasco P-1020 digital polarimeter. The UV spectra were obtained with a Jasco V-530 UV/VIS spectrophotometer, and IR spectra ( $\mathrm{KBr}$ or neat) were taken on a Perkin-Elmer System 2000 FT-IR spectrometer. 1D $\left({ }^{1} \mathrm{H},{ }^{13} \mathrm{C}\right.$, DEPT) and 2D (COSY, NOESY, HSQC, HMBC) NMR spectra using $\mathrm{CDCl}_{3}$ or acetone- $d_{6}$ or $\mathrm{CD}_{3} \mathrm{OD}$ as solvent were recorded on Varian Germini 2000-200 (200 MHz for ${ }^{1} \mathrm{H}$ NMR, $50 \mathrm{MHz}$ for ${ }^{13} \mathrm{C}$ NMR), Varian Unity Plus 400 (400 MHz for ${ }^{1} \mathrm{H}$ NMR, $100 \mathrm{MHz}$ for ${ }^{13} \mathrm{C}$ NMR) and Varian VNMRS-600 (600 MHz for ${ }^{1} \mathrm{H}$ NMR, $150 \mathrm{MHz}$ for ${ }^{13} \mathrm{C}$ NMR) spectrometers. Chemical shifts were internally referenced to the solvent signals in $\mathrm{CDCl}_{3}$ $\left({ }^{1} \mathrm{H}, \delta 7.26 ;{ }^{13} \mathrm{C}, \delta 77.0\right)$ or acetone- $d_{6}\left({ }^{1} \mathrm{H}, \delta 2.05 ;{ }^{13} \mathrm{C}, \delta 205.1\right)$ or $\mathrm{CD}_{3} \mathrm{OD}\left({ }^{1} \mathrm{H}, \delta 3.31 ;{ }^{13} \mathrm{C}, \delta 49.0\right)$, with TMS as the internal standard. ESIMS were obtained on an API 3000 mass spectrometer (Applied Biosystems) and HRESIMS on a Bruker Daltonics APEX II 30e mass spectrometer. Silica gels (70-230, 230-400 mesh) (Merck) were used for column chromatography (CC), and silica gel 60 F-254 (Merck) was used for analytical and preparative TLC. A spherical C18 100A column $(20-40 \mu \mathrm{M})$ (Silicycle) was used for medium-pressure liquid chromatography. 


\subsection{Plant Material}

Roots of B. tsangii were collected at Mudan, Pingtung County, Taiwan, in April 2009 and identified by one of the authors (I.-S.C.). A voucher specimen (Chen 6120) was deposited in the Herbarium of the School of Pharmacy, College of Pharmacy, Kaohsiung Medical University, Kaohsiung, Taiwan, Republic of China.

\subsection{Extraction and Isolation}

The dried roots $(7.9 \mathrm{~kg})$ of B. tsangii were sliced and extracted three times with cold $\mathrm{MeOH}(10 \mathrm{~L})$ at room temperature. The concentrated $\mathrm{MeOH}$ extract $(280 \mathrm{~g})$ inhibited nitrite production below $25 \%$, with no observed cytotoxicity at $100 \mu \mathrm{g} / \mathrm{mL}$. The $\mathrm{MeOH}$ extract was partitioned using EtOAc- $\mathrm{H}_{2} \mathrm{O}$ $(1: 1)$ to obtain EtOAc-soluble $(120 \mathrm{~g})$ and $\mathrm{H}_{2} \mathrm{O}$-soluble $(80 \mathrm{~g})$ fractions. The EtOAc solubles $(100 \mathrm{~g})$ were applied to a silica gel $\mathrm{CC}$ and eluted with $n$-hexane-EtOAc gradient solvent system (15:1 to $100 \%$ EtOAc) to obtain 13 fractions (A-1-A-13). Fractions A-4-A-13 showed inhibition of nitrite production using the anti-iNOS assay, and the $\mathrm{H}_{2} \mathrm{O}$-soluble fraction showed no inhibitory activity. CC of fraction A-8 (9.6 g) on silica gel, eluting with a gradient of $\mathrm{CH}_{2} \mathrm{Cl}_{2}$-EtOAc, yielded fractions A-8-1 to A-8-10. Fraction A-8-5 (416 mg) was subjected to MPLC (RP-18), eluting with acetone: $\mathrm{H}_{2} \mathrm{O}(3: 2)$, to obtain fractions A-8-5-1 to A-8-5-14. Fraction 8-5-6 (11.7 mg) was applied to preparative TLC ( $n$-hexane:acetone, 3:1) to obtain 6 (2.8 mg). Fraction A-8-5-14 (210 mg) was applied to MPLC (RP-18) eluting with acetone: $\mathrm{H}_{2} \mathrm{O}$ (2:1) to give 20 fractions (A-8-5-14-1-A-8-5-14-20). Fraction A-8-5-14-10 (20.8 mg) was separated over MPLC eluting with $n$-hexane:acetone (8:1) to afford 3 (1.2 mg). Fraction A-8-7 (1.97 g) was submitted to MPLC (RP-18), eluting with $\mathrm{MeOH}: \mathrm{H}_{2} \mathrm{O}(10: 1)$, to obtain fractions A-8-7-1 to A-8-7-14. Fraction A-8-7-6 (223 mg) was applied to MPLC and eluted with $n$-hexane: acetone (4:1) to obtain nine fractions (A-8-7-6-1-A-8-7-6-9). Fraction A-8-7-6-7 (5.5 mg) was purified by preparative TLC (RP-18) developed with $\mathrm{MeOH}: \mathrm{H}_{2} \mathrm{O}$ (15:1) to give 4 (4.4 mg). Fraction A-8-7-11 was subjected to MPLC and eluted with $n$-hexane: acetone (5:1) to yield $\mathbf{1 1}(5.7 \mathrm{mg})$. Fraction A-9 (17.8 g), on silica gel CC, eluting with a gradient of $n$-hexane-acetone, provided fractions A-9-1 to A-9-16. Fraction A-9-4 (104 mg) was applied to MPLC (RP-18) and eluted with acetone: $\mathrm{H}_{2} \mathrm{O}$ $(1: 1)$ to provide $7(1.6 \mathrm{mg})$ and 15 fractions (A-9-4-1-A-9-4-15). Fraction A-9-4-12 (3.6 mg) was purified by preparative TLC (RP-18) and developed with $n$-hexane:EtOAc (2:1) to give 10 (3.2 mg). Fraction A-9-4-4 was treated with the same step as fraction A-9-4-12 to yield 9 (1.1 mg). Fraction A-9-9 (587 mg) was separated over MPLC (RP-18), eluting with a system of acetone: $\mathrm{H}_{2} \mathrm{O}(1: 1)$, to afford fractions A-9-9-1 to A-9-9-21. Fraction A-9-9-2 (5 mg) and fraction A-9-9-10 (13.3 mg) were applied by preparative TLC developed with $\mathrm{CH}_{2} \mathrm{Cl}_{2}: \mathrm{MeOH}(70: 1)$ and $\mathrm{CH}_{2} \mathrm{Cl}_{2}$ :EtOAc $(8: 1)$ to give $8(2.5 \mathrm{mg})$ and $5(8.9 \mathrm{mg})$, respectively. Fraction A-9-9-20 (462 mg) was submitted to MPLC (RP-18) and eluted with acetone: $\mathrm{H}_{2} \mathrm{O}(3: 1)$ to afford fractions A-9-9-20-1 to A-9-9-20-15. Fraction A-9-9-20-6 $(63.8 \mathrm{mg})$ was subjected to MPLC (RP-18) and eluted with acetone: $\mathrm{H}_{2} \mathrm{O}(2: 1)$ to afford fractions A-9-9-20-6-1 to A-9-9-20-6-12. Fraction A-9-9-20-6-3 (3.8 mg) and fraction A-9-9-20-6-7 (13.3 mg) were purified by preparative TLC (RP-18), developed with $\mathrm{MeOH}: \mathrm{H}_{2} \mathrm{O}(5: 1)$ and acetone: $\mathrm{H}_{2} \mathrm{O}(2: 1)$, to give $\mathbf{1}(3.7 \mathrm{mg})$ and $\mathbf{2}(3.5 \mathrm{mg})$, respectively. 
Tsangibeilin C (1): Light yellowish oil; $[\alpha]_{\mathrm{D}}^{23} \pm 0\left(c 0.07, \mathrm{CHCl}_{3}\right)$; IR (neat) $v_{\max } \mathrm{cm}^{-1}: 3432$ (hydroxy group of carboxylic acid), $1696(\mathrm{C}=\mathrm{O})$; for ${ }^{1} \mathrm{H}$ and ${ }^{13} \mathrm{C}$ NMR spectroscopic data, see Table 1; ESIMS: $m / z 337[\mathrm{M}+\mathrm{Na}]^{+}$; HRESIMS: $m / z 337.1782[\mathrm{M}+\mathrm{Na}]^{+}$(calcd. for $\mathrm{C}_{20} \mathrm{H}_{26} \mathrm{O}_{3} \mathrm{Na}, 337.1780$ ).

Tsangibeilin D (2): Light yellowish oil; $[\alpha]_{\mathrm{D}}^{24} \pm 0\left(c 0.07, \mathrm{CHCl}_{3}\right)$; IR (neat) $v_{\max } \mathrm{cm}^{-1}: 3397(\mathrm{OH})$, $1692(\mathrm{C}=\mathrm{O})$; for ${ }^{1} \mathrm{H}$ and ${ }^{13} \mathrm{C}$ NMR spectroscopic data, see Table 1; ESIMS: $m / z 325[\mathrm{M}+\mathrm{Na}]^{+}$; HREIMS: $m / z 302.1879$ [M] ${ }^{+}$(calcd. for $\mathrm{C}_{19} \mathrm{H}_{26} \mathrm{O}_{3}, 302.1882$ ).

Tricyclotsangibeilin (3): Light yellowish oil; $[\alpha]_{\mathrm{D}}^{24}+36.3$ (c $0.024, \mathrm{CHCl}_{3}$ ); IR (neat) $v_{\max } \mathrm{cm}^{-1}$ : $3422(\mathrm{OH}), 1729(\mathrm{C}=\mathrm{O})$; for ${ }^{1} \mathrm{H}$ and ${ }^{13} \mathrm{C}$ NMR spectroscopic data, see Table 2; ESIMS: $m / z 341$ $[\mathrm{M}+\mathrm{Na}]^{+}$; HRESIMS: $m / z 341.2096[\mathrm{M}+\mathrm{Na}]^{+}$(calcd. for $\mathrm{C}_{20} \mathrm{H}_{30} \mathrm{O}_{3} \mathrm{Na}, 341.2093$ ).

Endiandric acid M (4): Light yellowish oil; $[\alpha]_{\mathrm{D}}^{25} \pm 0$ (c $\left.0.09, \mathrm{CHCl}_{3}\right)$; IR (neat) $v_{\max } \mathrm{cm}^{-1}: 3461$ (hydroxy group of carboxylic acid), $1694(\mathrm{C}=\mathrm{O}), 1040,937\left(\mathrm{OCH}_{2} \mathrm{O}\right)$; for ${ }^{1} \mathrm{H}$ and ${ }^{13} \mathrm{C}$ NMR spectroscopic data, see Table 2; ESIMS: $m / z 373[\mathrm{M}+\mathrm{Na}]^{+}$; HRESIMS: $m / z 373.1418[\mathrm{M}+\mathrm{Na}]^{+}$ (calcd. for $\mathrm{C}_{22} \mathrm{H}_{22} \mathrm{O} 4 \mathrm{Na}, 373.1416$ ).

Beilschminol B (5): Light yellowish oil; $[\alpha]_{\mathrm{D}}^{25}-18.6$ (c 0.18, MeOH); UV (MeOH) $\lambda \max (\log \varepsilon): 209$ (4.63), $240 \mathrm{sh}$ (3.92), 270 (3.12) nm; UV (MeOH+KOH) $\lambda \max (\log \varepsilon): 210$ (4.71), $242 \mathrm{sh}$ (3.97), 280 (3.25) nm; IR (neat) $v_{\max } \mathrm{cm}^{-1}: 3415(\mathrm{OH}), 1593,1508,1461$ (benzene ring); ${ }^{1} \mathrm{H}$ NMR (400 MHz, $\left.\mathrm{CDCl}_{3}\right) \delta 1.07\left(3 \mathrm{H}, \mathrm{d}, J=6.0 \mathrm{~Hz}, \mathrm{H}-99^{\prime}\right), 1.08(3 \mathrm{H}, \mathrm{d}, J=6.0 \mathrm{~Hz}, \mathrm{H}-9), 1.78$ (2H, m, H-8, H-8'), 3.83 $\left(3 \mathrm{H}, \mathrm{s}, \mathrm{OCH}_{3}-4^{\prime}\right), 3.88\left(12 \mathrm{H}, \mathrm{s}, \mathrm{OCH}_{3}-3^{\prime}, \mathrm{OCH}_{3}-4, \mathrm{OCH}_{3}-5, \mathrm{OCH}_{3}-5^{\prime}\right), 4.61(1 \mathrm{H}, \mathrm{d}, J=8.8 \mathrm{~Hz}, \mathrm{H}-7)$, $4.63\left(1 \mathrm{H}, \mathrm{d}, J=9.2 \mathrm{~Hz}, \mathrm{H}-7^{\prime}\right), 5.78\left(1 \mathrm{H}\right.$, br s, $\mathrm{D}_{2} \mathrm{O}$ exchangeable, OH-3), $6.55(1 \mathrm{H}, \mathrm{d}, J=1.8 \mathrm{~Hz}$, H-6), $6.61\left(2 \mathrm{H}, \mathrm{s}, \mathrm{H}-2\right.$ ', H-6'), $6.64(1 \mathrm{H}, \mathrm{d}, J=1.8 \mathrm{~Hz}, \mathrm{H}-2) ;{ }^{13} \mathrm{C} \mathrm{NMR}\left(100 \mathrm{MHz}, \mathrm{CDCl}_{3}\right) \delta 13.9$ (C-9'), 14.0 (C-9), 50.9 (C-8'), $51.0(\mathrm{C}-8), 55.9\left(\mathrm{OCH}_{3}-5\right), 56.1\left(\mathrm{OCH}_{3}-3^{\prime}, \mathrm{OCH}_{3}-5^{\prime}\right), 60.8\left(\mathrm{OCH}_{3}-4^{\prime}\right)$, $60.9\left(\mathrm{OCH}_{3}-4\right), 88.2$ (C-7), 88.5 (C-7'), 101.6 (C-6), 102.9 (C-2', C-6'), 105.8 (C-2), 134.7 (C-4), 137.2 (C-4'), 138.0 (C-1'), 138.7 (C-1), 149.1 (C-3), 152.4 (C-5), 153.2 (C-3', C-5'); ESIMS: m/z 441 [M + Na]'; HRESIMS: $m / z 441.1887[\mathrm{M}+\mathrm{Na}]^{+}$(calcd. for $\mathrm{C}_{23} \mathrm{H}_{30} \mathrm{O} 7 \mathrm{Na}, 441.1889$ ).

(+)-5-Hydroxybarbatenal (6): Light yellowish oil; $[\alpha]_{\mathrm{D}}^{25}+123.8\left(\mathrm{c} 0.06, \mathrm{CHCl}_{3}\right)$; IR (neat) $v_{\max } \mathrm{cm}^{-1}$ : $3408(\mathrm{OH}), \quad 1681(\mathrm{C}=\mathrm{O})$; for ${ }^{1} \mathrm{H}$ and ${ }^{13} \mathrm{C}$ NMR spectroscopic data, see Table 3; ESIMS: $m / z 257[\mathrm{M}+\mathrm{Na}]^{+}$; HRESIMS: $m / z 257.1516[\mathrm{M}+\mathrm{Na}]^{+}$(calcd. for $\mathrm{C}_{15} \mathrm{H}_{22} \mathrm{O}_{2} \mathrm{Na}, 257.1517$ ).

(4R,5R)-4,5-Dihydroxycaryophyll-8(13)-ene (7): Light yellowish oil; $[\alpha]_{\mathrm{D}}^{25}-23.9$ (c $0.032, \mathrm{CHCl}_{3}$ ); IR (neat) $v_{\max } \mathrm{cm}^{-1}: 3396(\mathrm{OH}), 1637(\mathrm{C}=\mathrm{C})$; for ${ }^{1} \mathrm{H}$ and ${ }^{13} \mathrm{C}$ NMR spectroscopic data, see Table 3; ESIMS: $m / z 261[\mathrm{M}+\mathrm{Na}]^{+}$; HRESIMS: $m / z 261.1828[\mathrm{M}+\mathrm{Na}]^{+}$(calcd. for $\mathrm{C}_{15} \mathrm{H}_{26} \mathrm{O}_{2} \mathrm{Na}, 261.1830$ ).

\section{Conclusions}

There are about 200 Beilschmiedia species in the tropical regions mentioned earlier, including two species in Taiwan [1]. Except for the two species in Taiwan, previous studies of nine Beilschmiedia species in the world have revealed endiandric acids [5,18,19], flavonoids [20,21], alkaloids [22-24], benzopyrans [18], arylpropanoids [25] and sesquiterpenoids [18]. Several isolates have shown antibacterial [19,21] and antimalarial [22] activities. Phytochemical studies of the two Formosan Beilschmiedia species have been carried out by our group, analyzing the stems [2], the leaves [3] and the roots [4] of B. tsangii, together with the roots [8,9] of B. erythrophloia. Both species possess endiandric acids, 7,7'-epoxylignans, 7',8'-seco-7,7'-epoxylignans, benzopyrans, arylpropanoids, amides, sesquiterpenoids and steroids. In this study, endiandric acids, 7,7'-epoxylignans, benzenoid, 
sesquiterpenoids and triterpenoid were also reported. The constituents of the roots of the two Formosan Beilschmiedia species showed 19 new endiandric acid analogues as key secondary metabolites. The roots of other Beilschmiedia species found in other regions have not yet been studied. However, several isolates from two Formosan Beilschmiedia species have shown cytotoxic [2], anti-tubercular [3,9] or anti-inflammatory activities [4] in previous studies. These three bioactivities have not yet been examined in other members of the Beilschmiedia genus.

\section{Acknowledgments}

This research was kindly supported by the National Science Council of the Republic of China (NSC 99-2320-B-037-009) and the Kaohsiung Medical University Research Foundation (KMUER013).

\section{Conflict of Interest}

The authors declare no conflict of interest.

\section{References}

1. Liao, J.C. Lauraceae. In Flora of Taiwan, 2nd ed.; Editorial Committee of the Flora of Taiwan: Taipei, Taiwan, 1996; Volume 2, pp. 433-499.

2. Chen, J.J.; Chou, E.T.; Duh, C.Y.; Yang, S.Z.; Chen, I.S. New cytotoxic tetrahydrofuran- and dihydrofuran-type lignans from the stem of Beilschmiedia tsangii. Planta Med. 2006, 72, 351-357.

3. Chen, J.J.; Chou, E.T.; Peng, C.F.; Chen, I.S.; Yang, S.Z.; Huang, H.Y. Novel epoxyfuranoid lignans and antitubercular constituents from the leaves of Beilschmiedia tsangii. Planta Med. 2007, 73, 567-571.

4. Huang, Y.T.; Chang, H.S.; Wang, G.J.; Chen, C.H.; Lin, C.H.; Yang, Y.Z.; Chen, I.S. Anti-inflammatory endiandric acid analogues from the roots of Beilschmiedia tsangii. J. Nat. Prod. 2011, 74, 1875-1880.

5. Chouna, J.R.; Nkeng-Efouet, P.A.; Lenta, B.N.; Wansi, J.D.; Kimbu, S.; Sewald, N. Endiandric acid derivatives from the stem bark of Beilschmiedia anacardioides. Phytochem. Lett. 2010, 3, 13-16.

6. Bandaranayake, W.M.; Banfield, J.E.; Black, D.S.C.; Fallon, G.D.; Gatehouse, B.M. Constituents of Endiandra species. I. endiandric acid, a novel carboxylic acid from Endiandra introrsa (Lauraceae), and a derived lactone. Aust. J. Chem. 1981, 34, 1655-1667.

7. Bandaranayake, W.M.; Banfield, J.E.; Black, D.S.C.; Fallon, G.D.; Gatehouse, B.M. Constituents of Endiandra species. III. 4-[(E,E)-5'-phenylpenta-2',4'-dien-1'-yl]tetracyclo $\left[5,4,0,0^{2,5}, 0^{3,9}\right]$ undec10-ene-8-carboxylic acid from Endiandra introrsa (Lauraceae). Aust. J. Chem. 1982, 35, 567-579.

8. Yang, P.S.; Cheng, M.J.; Chen, J.J.; Chen, I.S. Two new endiandric acid analogs, a new benzopyran, and a new benzenoid from the root of Beilschmiedia erythrophloia. Helv. Chim. Acta 2008, 91, 2130-2138.

9. Yang, P.S.; Cheng, M.J.; Peng, C.F.; Chen, J.J.; Chen, I.S. Endiandric acid analogues from the roots of Beilschmiedia erythrophloia. J. Nat. Prod. 2009, 72, 53-58. 
10. Adio, A.M.; Konig, W.A. Sesquiterpenoids and norsesquiterpenoids from three liverworts. Tetrahedron 2007, 18, 1693-1700.

11. Collado, I.G.; Hanson, J.R.; Hitchcock, P.B.; Macias-Sanchez, A.J. Stereochemistry of epoxidation of some caryophyllenols. J. Org. Chem. 1997, 62, 1965-1969.

12. Pouchert, C.J.; Behnke, J. The Aldrich Library of ${ }^{13} \mathrm{C}$ and ${ }^{1} H$ FT NMR Spectra, 1st ed.; Aldrich Chemical Co., Inc.: Wisconsin, WI, USA, 1993; Volume 2, p. 964.

13. Iijima, T.; Yaoita, Y.; Kikuchi, M. Five new sesquiterpenoids and a new diterpenoid from Erigeron annuus (L.) Pers., Erigeron philadelphicus L. and Erigeron sumatrensis Retz. Chem. Pharm. Bull. 2003, 51, 545-549.

14. Zhang, H.J.; Tan, G.T.; Santarsiero, B.D.; Mesecar, A.D.; Van Hung, N.; Cuong, N.M.; Soejarto, D.D.; Pezzuto, J.M.; Fong, H.H.S. New sesquiterpenes from Litsea verticillata. J. Nat. Prod. 2003, 66, 609-615.

15. Kamel, A. 7-epi-Eudesmanes from Teucrium polium. J. Nat. Prod. 1995, 58, 428-431.

16. Bilia, A.R.; Mendez, J.; Morelli, I. Phytochemical investigations of Licania genus. Flavonoids and triterpenoids from Licania carii. Pharm. Acta Helv. 1996, 71, 191-197.

17. Min, B.S.; Kim, Y.H.; Lee, S.M.; Jung, H.J.; Lee, J.S.; Na, M.K.; Lee, C.O.; Lee, J.P.; Bae, K.H. Cytotoxic triterpenes from Crataegus pinnatifida. Arch. Pharm. Res. 2000, 23, 155-158.

18. Banfield, J.E.; Black, D.S.C.; Collins, D.J.; Hyland, B.P.M.; Lee, J.J.; Pranowo, S.R. Constituents of some species of Beilschmiedia and Endiandra (Lauraceae): New endiandric acid and benzopyran derivatives isolated from B. oligandra. Aust. J. Chem. 1994, 47, 587-607.

19. Chouna, J.R.; Nkeng-Efouet, P.A.; Lenta, B.N.; Devkota, K.P.; Neumann, B.; Stammler, H.G.; Kimbu, S.; Sewald, N. Antibacterial endiandric acid derivatives from Beilschmiedia anacardioides. Phytochemistry 2009, 70, 684-688.

20. Harborne, J.B.; Mendez, J. Flavonoids of Beilschmiedia miersii. Phytochemistry 1969, 8, 763-764.

21. Lenta, B.N.; Tantangmo, F.; Devkota, K.P.; Wansi, J.D.; Chouna, J.R.; Soh, R.C.F.; Neumann, B.; Stammler, H.G.; Tsamo, E.; Sewald, N. Bioactive constituents of the stem bark of Beilschmiedia zenkeri. J. Nat. Prod. 2009, 72, 2130-2134.

22. Kitagawa, I.; Minagawa, K.; Zhang, R.S.; Hori, K.; Doi, M.; Inoue, M.; Ishida, T.; Kimura, M.; Uji, T.; Shibuya, H. Dehatrine, an antimalarial bisbenzylisoquinoline alkaloid from the Indonesian medicinal plant Beilschmiedia madang, isolated as a mixture of two rotational isomers. Chem. Pharm. Bull. 1993, 41, 997-999.

23. Tillequin, F.; Koch, M.; Pusset, J.; Chauviere, G. Two new morphinane alkaloids from Beilschmiedia oreophila Schlechter (Lauraceae). Heterocycles 1985, 23, 1357-1361.

24. Johns, S.R.; Lamberton, J.A.; Sioumis, A.A.; Tweeddale, H.J. New aporphine alkaloids from Beilschmiedia podagrica. Aust. J. Chem. 1969, 22, 1277-1281.

25. Kumamoto, J.; Scora, R.W. Structure of sarisan, an isomer of myristicin, isolated from the leaf oil of Beilschmiedia miersii. J. Agric. Food Chem. 1970, 18, 544-545.

(C) 2012 by the authors; licensee MDPI, Basel, Switzerland. This article is an open access article distributed under the terms and conditions of the Creative Commons Attribution license (http://creativecommons.org/licenses/by/3.0/). 